\title{
Chapter 10 \\ The Hive and the Pendulum: Universal \\ Metrology and Baroque Science
}

\author{
Nicholas Dew
}

\begin{abstract}
Early modern scholars and statesmen were acutely aware of the need for improved standards of measurement, albeit for differing reasons. The variety of man-made units across territories and histories was, by the seventeenth century, already a sceptical commonplace, and was understood in terms of the mutability of human institutions. The late seventeenth century saw many scholars advance possible candidates for a universal standard. The most promising of these was the use of a seconds pendulum as a standard for length, a project which was actively pursued by the French Académie Royale des Sciences in the 1670s and 1680s, and remained a goal cherished by savants through the eighteenth century. This paper's first section places the Académie's early metrological projects in the context of the scholarly community's ideal of a universal measurement standard, which was often expressed in ways combining political, theological, and humanistic concerns. Melchisédech Thévenot's ludic proposal that honeycombs might be a length standard is explored as one example. The second section examines the Académie's attempts to test the seconds pendulum as a universal length standard, by taking the missions to Uraniborg (1671) and to London (1679) as case studies in the practice of metrological work.
\end{abstract}

\section{The Hive: Universal Measurement in Baroque Theory}

Towards the end of May 1680, London was hit by a hailstorm. Even in the "little ice age" of the seventeenth century, this was uncommon for the time of year. The curious virtuosi rushed into the streets to measure the dimensions of the hailstones. One of these virtuosi was John Locke, who sent news of this strange event to his French

\footnotetext{
N. Dew $(\bowtie)$

Department of History and Classical Studies, McGill University, Montreal, QC, Canada

e-mail: nicholas.dew@mcgill.ca
} 
friend, Nicolas Toinard: "Last Tuesday hailstones of enormous size fell all over the city here. I myself measured one lump of ice ... which had a circumference of 420 grys..." (Locke 1976-1989, 2: 175-6 [Locke to Toinard, 20 May 1680]). ${ }^{1}$ Toinard read the letter to the group of Locke's friends in Paris, a group which included François Bernier, Jean Picard, Eusèbe Renaudot, Henri Justel, and Melchisédech Thévenot, among others. The French curieux marvelled at Locke's news-after all, a hailstorm in late May was a strange fact-but were more concerned about interpreting the measurement. The hailstones, Locke said, had a circumference of 420 grys - which sounded rather large — but none of the French knew what this strange English unit, the gry, was. Toinard had asked his friends who knew some English (like Thévenot and Adrien Auzout), but none of them were familiar with the term. Toinard therefore begged Locke to explain the mystery (Locke 1976-1989, 2: 183 [Toinard to Locke, 27 May 1680]).

Locke replied, apologetically. The gry, as he thought he had already explained to Toinard, was a unit of his own invention. A few years earlier, while on his travels around France, he had devised his own measurement system, which was designed to be both rational (being partly decimal) and universal (being based on a naturallyoccurring constant). The gry was one thousandth of the "philosophical foot". The philosophical foot was to be divided into 10 inches, each inch into 10 lines, and each line into 10 grys (Locke 1976-1989, 2: 194 [Locke to Toinard, 10 June 1680]). ${ }^{2}$ The philosophical foot—also known as the "universal foot"- was one third of the philosophical (or universal) yard. The philosophical yard was the length of a pendulum beating seconds, which was at this time a popular candidate for a universal standard of measurement, not least because it was conveniently close to most existing yard lengths. The gry was, then, roughly a third of a modern millimetre, so Locke's hailstones with their circumference of 420 grys were about $41 / 2 \mathrm{~cm}$ in diameter.

Locke's news may have been about meteorology, but what matters for my purposes is the metrology. This minor episode of miscommunication between Locke and the French savants encapsulates, in many ways, the metrological problem that faced the scientific community of the late seventeenth century. Two things are important. The first is the fact that Locke has developed a rational measurement system derived from a supposed natural constant: in this, he is representative of the ambitions of the savant community at large. The second is the very untranslatability of his reported data ("420 grys"), which is representative of the acute problems inherent in the communication of measurements in this period. Locke's system was still only a private one, although he hoped it would one day be adopted. This only underlines for us that measurements could only be communicated if a shared system existed-but in order to establish such a system, special objects, techniques, and individuals had to travel from place to place. The chaotic diversity of weights and measures in ancien régime Europe was, of course, a familiar problem (Kula 1985, 161-184; Zupko 1978; Haustein 2001; Alder 1995). For instance, in the very same exchange of letters, Locke had also asked Toinard if he could translate some measurement terms from Montpellier-because a friend there had sent him a recipe for baking bread, and he wanted to know what the measures in the recipe meant (they were: "une truquette d'eau", "une piche d'eau", and "une hemine de farine"). These units from Lower 
Languedoc were unknown in Paris, so Toinard had promised to send for accurate information on the spot ("sur les lieux"), adding that all he knew was "that their pound is 4 ounces less than ours" (Locke 1976-1989, 2: 175, 182-83). ${ }^{3}$

Both of these instances, the Montpellier bread-making recipe and the hailstones of London, remind us that problems of metrology had spatial as well as historical dimensions. To put this another way: the first thing to do, when faced with a measurement-translation problem in the seventeenth century, was to write to friends in other places, to ask for a unit's value in relation to some known unit; if that failed, to ask for specimens of the units to be sent; and then, if that also failed, the only thing left to do was to travel, to remove all mediation, and to directly measure the reference objects. First letters circulated; then metal rules; then people. Existing measurement systems were commonly defined by their territorial extent, standards usually being named after the city or province that defined them. So universal measurement schemes were, literally, utopian. In reply to Locke's wish that "that people might some day agree upon the philosophic foot" (175), Toinard agreed heartily with the principle, but was sceptical about its practicality, adding, only half jokingly, that it would perhaps only be possible to institute Locke's system in America - specifically in the colony of Carolina, for which Locke had helped draft the constitution - since there, things could be "cut from a fresh cloth". Toinard adds, tantalisingly, that he has heard a rumour that "a country" is considering adopting the universal yard, but he doesn't dare say which one (Locke 1976-1989, 2: 182-183 [Toinard to Locke, 27 May 1680]). ${ }^{4}$ Meanwhile, with such schemes still pending general adoption, savants like Locke travelled around, continually noting the various values of the coins, weights and measures they found as they toured from one town to the next. Locke, when he was in Paris in 1677, had paid the English-born instrument maker, Michael Butterfield, to make him a brass rule, upon which were inscribed the units of London, Paris, Leiden, Copenhagen, and Rome, along with the philosophical foot for comparison. This he used to take measurements when visiting the Roman ruins in Nîmes, and the Châteaux of the Loire (Locke 1953).

Like universal language schemes, projects for a universal system of measurement were widespread at this time, and were usually discussed in the rhetoric of the "Republic of Letters". For example, Locke, when introducing his scheme in his Essay Concerning Human Understanding, says a decimal system would be of "general convenience" in the "Commonwealth of Letters" (Locke 1975, 624 [IV.10.10. note a]; cf. Locke 1976-1989, 2: 39). At the same time, seventeenthcentury savants all knew that measurement standards were tied to local forms of authority: political theory in the period conventionally identified the authority over weights and measures as one of the "marks of sovereignty" (e.g. Bodin 1583, 244; Bodin 1992, 80-1 [book 1, ch. 10]). This meant that a legally instituted universal system might only see the light under a "universal monarchy". So savants were aware of the distinction between a metrological system conceived as a convention to be voluntarily adopted by a scientific community, and one to be imposed upon a really existing economy (as was to be attempted by the French Revolutionary governments: Alder 1995; Heilbron 1993, 243-77; Baker 1990, 156-159). Even if it still seemed unlikely, to late seventeenth-century thinkers, to be something that 
any European state might actually impose (despite Toinard's rumour), a "philosophical" measurement system could at least be set up as a convention among scholars, and it could also allow for past and present measures to be passed on to posterity. There remained, nonetheless, a tension between the value that might be attached to a standard owing to its widespread use and its convenience, and the value attached to those measurement standards that were thought to have the moral authority of either God, Nature, or of the Ancients (or a combination of these).

Humanists had long been troubled by their ignorance of the true values for the Roman foot or Hebrew cubit. In the 1640s, John Greaves had provided one of the most thorough investigations of the problem of Roman weights and lengths, based on his antiquarian travels in the eastern Mediterranean (Shalev 2002). Greaves concluded his book by suggesting that the most reliable way to provide posterity with standards of conversion between ancient and contemporary metrics was to use long-standing monuments, like the pyramids, as physical standards (Greaves 1647, 123-8). In a more ecclesiastical register, though, it was not uncommon to associate the ancient Hebrew values with divine (and therefore also natural) authority (Bennett and Mandelbrote 1998). It should not be surprising that the English churchman Richard Cumberland, best known as a theorist of natural law, also wrote a treatise on the values of the ancient Hebrew measures, which was printed by the Royal Society's printer in 1686. Cumberland, in his dedicatory letter to Samuel Pepys (then the Society's president), cast his metrological researches as both eirenic and commercial, calling it "the peaceable Doctrine of Measures and Weights, which in their General Nature, are the Common Concern of all Mankind; as being the necessary Instruments of just Dealing, and fair Commerce between all Nations". Cumberland went on to argue that the ancient Hebrew measures were likely to contribute to peaceful commerce because they were "the Rules of that Righteousness, whereof Noah, the Father of all Men now living, was a Preacher". He concluded the book by suggesting the seconds pendulum be used as a universal measure (Cumberland 1686, sig. A6r-7r, 124-27).

Two decades earlier, John Wilkins, another prominent English divine, and also closely linked to the Royal Society, had already made explicit the connection between reforming language and reforming metrology, in his Essay Towards a Real Character, and Philosophical Language, probably the best-known language-reform scheme to emerge from England (Lewis 2007). In the second part of the Essay, Wilkins discussed the problem of a "natural standard, or universal Measure" (he identifies the two), noting that it was "esteemed by Learned men as one of the desiderata in Philosophy" (Wilkins 1668, 191-2). Ancient measures had once been derived from natural objects, such as the width of a grain of barley, or the various anthropometric measures (the inch, palm, span, cubit, foot, pace, and so on), but none of these were suitably invariant. The current candidates for a length standard included a division of a meridian arc, which had been suggested by Gabriel Mouton, a Lyon cleric (Mouton 1670), and which was later to be revived in the French Revolutionary metric system, as well as a proposal using "the Quick-silver experiment" (i.e. a column of mercury in a Torricellian apparatus). The first Wilkins thought too difficult to achieve with any certainty, and the second obviously too subject to 
variations in the "gravity and thickness of the Atmosphere, together with the various tempers of the Air in several places and seasons". He therefore proposed (citing Wren, Brouncker, and Huygens) the length of a seconds pendulum, which was presumed to be less subject to local and temporal variation, and went on, just as Locke did later, to divide the resulting unit in decimal fashion, complete with derived units of capacity and weight (Wilkins $1668,191-2){ }^{5}$

French scholars were engaged in a similar range of antiquarian, theological, and natural-philosophical discussions of metrology. Claude Lancelot, who had written, with Antoine Arnauld, the Port-Royal Grammar of 1660, which reflected on the basis for translation between languages, wrote an erudite treatise on the antique capacity unit, the "hémine", largely in order to resolve debates among religious communities over the precise daily ration of wine allowed by the rule of Saint Benedict (Lancelot 1667). Meanwhile, one of Locke's friends, the collector and scientific academy host Melchisédech Thévenot, was also interested in the problem of a universal measure, and proposed a rather striking solution.

In a "Discourse on the Art of Navigation", published as an appendix to a collection of travel accounts which was itself an annex to his larger travel collection (Dew 2006), Thévenot discussed the problem of transmitting measurement standards across time and space. The passage is worth quoting in full:

In an enterprise in which so many projects have failed that it has come to seem almost hopeless, it occurred to me that perhaps we would have more success by using one of those creations that we say animals make by instinct; we could, it seems to me, reasonably suppose that this instinct, being based in an eternal cause, must always be the same, and exempt from the varieties which distinguish everything that comes from men. Among other examples, I found that the cells made by bees of the same species, measured at the time that the bees build them, are equal among themselves, and having since measured those near to Paris, Leiden, and Florence, I found no difference; and if one follows the lines according to which the bottoms or bases of these cells are arranged, one will find that the same number of cells always comes to the same measurement. Thus, if all of the measures that are currently used in the world were to be reduced to that of the bees, posterity would by this means be able to know them all: and this measure, which I here propose, would be all the more universal [générale], since there are bees in every part of the world, in polar regions just as in places near the equator. And even though I build it on wax, nothing stops me from believing that this [unit] could last as long as the world, and that it is more apt for this design than the jasper [diaspre] ${ }^{6}$ of the tomb upon which Gravius [John Greaves] marked the English foot, and easier to understand and to put into practice than the measure based on the oscillations of a pendulum combined with astronomical observations, as has been proposed in France and in Poland. But, before being able to establish it, I would like to be able to compare the works [ouvrages] of bees in distant places, those from the Cape of Good Hope and from Egypt, for example, with those from Muscovy and from Mexico, etc. And if they are found to be equal everywhere, this measure could be made common to all nations, and by this means we could transmit the knowledge of the measurement systems of our age to posterity-which is what we are seeking to do (Thévenot 1681, separately paginated, 23-25). ${ }^{7}$

The passage is typical of that ludic style in natural philosophical writing which Paula Findlen has identified as common currency in the "culture of curiosity", from Kepler down to at least Leibniz (Findlen 1990, 1998). That Thévenot's suggestion was playful does not mean that the idea lacked any seriousness. Thévenot notes that 
honeybees made their cells by "instinct", and that this guarantees their constancy: since animal instinct could reasonably be supposed to come from an unchanging "eternal cause" (or by the "hand of God", as he puts it further on), honey-bees must be exempt from human mutability. Thévenot also specifies, as if to add plausibility to his claim, that the honeycombs must be freshly made, and that one must only compare honeycombs made by bees of the same species, though he does not say which. The regularity of the cells was something, he goes to add, that Aldrovandi and Muffet, and all those other "personnages de grande lecture, who believed themselves to have got to the bottom of bee-research simply by collecting everything that the Ancients and Moderns had written about them", had failed to notice (Thévenot 1681, 25-26). Thévenot also notes that of the three most common tessellating shapes (the square, the triangle and hexagon) the hexagon contains the largest area. Bees have managed, through animal instinct alone, to construct their cells according to the optimum shape, something that only the most able geometers might have calculated.

Thévenot goes on: "Thus, one might apply to these workers the verses that the Poet applied to himself, and say, in tenui labor, at tenuis non gloria ['little the scale to work on, yet not little the glory'], or indeed allow a Persian Poet to exclaim, with the license common to the poets of his country, that if Archimedes had examined such a surprising structure (ouvrage), he would have "bitten the fingers of admiration with the teeth of envy"" (Thévenot 1681, 27; cf. Virgil 1982, 124). ${ }^{8}$ Alongside this nod to the Orientalist erudition for which he was known (Dew 2009), Thévenot here made what was, for his readers, the obvious allusion to the fourth book of Virgil's Georgics (IV.6), reminding readers of the long tradition in which bees' labour could be compared to human labour, and the bee hive used as a metaphor for the human polity (Virgil 1982, 124-43; cf. Pliny 1991, 149-157 [book 11]; Burke 1997; Allen 2004; Woolfson 2010). ${ }^{9}$

Although published in 1681, Thévenot had been working on his apian metrology at least 10 years earlier. From his country home at Issy (outside Paris), he had been able to support the work of both Jan Swammerdam and Niels Steno, both of whom collected and dissected insects during their time with him. Thévenot had announced his measurement idea in a letter to Henry Oldenburg in 1671 (28 October 1671; Oldenburg 1965-1986, 8: 310-11), which uses language almost identical to that of the version he later published. Around the same time, Thévenot had built a glass hive with which to observe bee behaviour. Thévenot's friend, the Gassendist philosopher and traveller, François Bernier, in a satirical edict mocking the Sorbonne's motions against the new science, mentions Thévenot's use of a glass hive, and casts him as a spy working maliciously against the Republic of Bees, out of disregard for the teachings of Aristotle (Bernier 1992 [1671], 235).

Bees were a common rhetorical resource for natural philosophers in the midcentury, and interpreting them was, thanks to Virgil, always tied up with emblematic significance. The idea of using a glass hive to observe bee life was something that Thévenot could have learned from his contemporaries in the culture of curiosity. In the Hartlib circle, around 1650, there was discussion of a glass hive made by the Gloucestershire parson William Mewe, which inspired Hartlib to pursue bee research over several years, inspiring others (including Wilkins and Wren) to design glass hives 
and to write about the "republic of bees", pointing economic lessons for the English interregnum Commonwealth (Hartlib 1655, 52; Raylor 1992; Johns 1998, 266-71; Bennett and Mandelbrote 1998, 162-3). Earlier still, bee research had been a part of the Lincean academy's natural historical work in Rome in the 1620s, not least because the bee was the emblem of the Barberini family, under whose patronage the Linceans worked (Freedberg 2002, 151-94; Findlen 1994, 214-6, 378-80). Bee research frequently brought forth political commentary, either playful or serious, in the scientific culture of the period. But if bees had long been endowed by humans with the power to suggest solutions to the problem of social order, Thévenot was now endowing them with the power to provide a solution to a problem of knowledge. ${ }^{10}$

\section{The Pendulum: Establishing a Metrological Network in Practice}

Thévenot seems to have been the only scholar to suggest that honeycomb cells were sufficiently regular to become the basis of a universal length standard. The length of a pendulum beating seconds, however, was more widely accepted as a potential candidate, and had been discussed in these terms, as we have seen, by several English savants, but also on the continent by Mersenne, by Huygens, and by the Poland-based Italian Jesuit, Tito-Livio Burattini (Koyré 1953; Blamont 2001; Armogathe 2001; Giustini 1992). Even while it was being advanced as a candidate, though, there were always concerns about possible problems with the seconds pendulum. As early as 1620, Bacon, in the New Organon, had already speculated that weight might vary with altitude (Bacon 2000, 163-4 [book 2, aphorism 36]), and in the 1660s there was a common concern that the pendulum's motion would vary with differing climates, atmospheric conditions, and with latitude. (Boyle and Brouncker in 1661 had proposed that someone take a pendulum clock up the Pico Tenerife, to test the effects of varying atmospheric pressure on a pendulum). Christiaan Huygens, who had done more work on pendulums than most, argued in the 1660s for the seconds pendulum as a length standard, but was also concerned, as early as 1666, about possible variations in weight with latitude, since he thought that the earth's rotation would produce a centrifugal force in the atmospheric vortex, which would cause bodies to lose weight when close to the equator (Huygens 1986, 167-70; Defossez 1946, 153-67; Costabel 1987; cf. Matthews 2000).

The seconds pendulum was therefore both a leading candidate for a length standard, and yet, at the same time, its candidacy was being challenged by theoretical objections, even before any experimental data from diverse locations had been gathered. What made the data available was the mapping expeditions organized by the French Académie Royale des Sciences and centred on the Paris Observatoire. From its very foundation (1666) the Académie was planning expeditions to advance astronomy, geodesy, and cartography. The interest of the savants in using new techniques to improve their figures for fundamental units like the size of the earth, and the distance from the earth to the sun, was cannily married to the interests of the king and his ministers, with projects like the remapping of France, the establishment 
of the Paris meridian, and the project to map the whole world from the Paris Observatoire. To these ends, the Paris academy organized a series of expeditions around France — but also further afield —-from around 1670 onwards (Olmsted 1942, 1960). Since it was already a seemingly good candidate for a universal measure, and yet still shrouded in theoretical doubt, the measurement of a seconds pendulum was added - even in the earliest proposals for voyages - to the list of instructions for the Académie's envoys (albeit as a secondary task, supplementing their astronomical work). ${ }^{11}$ The abbé Jean Picard, in his 1671 Mesure de la Terre, effectively announced the Académie's commitment to the seconds pendulum as a length standard, and also gave one of the fullest discussions of how the measurement should be done (Picard 1671, 3-5). Through the 1670s, figures were collected from a range of locations across Europe. Two occasions will be taken as examples here: Picard's measurement made in 1671 at Uraniborg, and Rømer's in London in 1679.

\section{Picard in Uraniborg, 1671}

Picard's mission to Uraniborg in 1671 was among the earliest of the Académie des sciences's overseas astronomical expeditions. Initially, the Académie had hoped to send a mission to Madagascar (McKeon 1965, 246-57; Olmsted 1942, 118-9). The target was then revised to a mission to Alexandria, in Egypt. This also proved too ambitious, and the Académie had to settle for a cheaper alternative: the Baltic. The aim was to use modern instruments and techniques - telescopes fitted with micrometers, pendulum clocks, and the concerted observation of Jupiter's satellites - to find the difference in longitude between Paris and Uraniborg (since the available figures differed), so that the observations of Tycho Brahe, made there almost a century earlier, could be reduced to the Paris meridian. The Uraniborg mission was an exercise in translation, in several senses. Locating Uraniborg precisely in relation to Paris would allow the French to translate Tycho's figures onto a Parisian standard. At the same time, the French were interested in appropriating an existing project to produce a new edition of Tycho's papers, to improve the error-prone text of Kepler's Rudolphine Tables. The intended publication of the corrected Tycho at the Imprimerie royale under the patronage of Louis XIV would effect a symbolic translation of the prestige of Uraniborg to Paris (Pedersen 1987; Cassini 1693, 40-1; Picard 1693).

Picard left Paris in July 1671, with a battery of instruments and a young trainee named Etienne Villiard. They visited Leiden en route, where Picard was able to converse with the great cartographer Blaeu about geodesy, and to purchase a piece of luminous Icelandic spar. ${ }^{12} \mathrm{He}$ was also able to measure a standard for the Rhenish foot. ${ }^{13}$ After visiting Hamburg en route, they arrived in Copenhagen, where they were received by the local savants. The French were surprised to learn that the island of Hven, on which Uraniborg was built, was no longer a Danish possession, but was under Swedish control (as it had been since 1660). Such details of Baltic diplomacy had not reached the Académie. The operations on Hven were organized from the 
round tower of the Copenhagen Observatory, where Picard's host was Erasmus Bartholin, professor of mathematics and medicine there. Bartholin introduced Picard to a young and gifted student of his, Ole Rømer, and the four of them (Picard, Villiard, Bartholin and Rømer) sailed over to Hven together. Bartholin was already working on the new edition of Tycho, and his cooperation was essential both for the Uraniborg mission and for the publication project. For his part, Picard seemed concerned to make sure that news of his visit did not reach England-it seems because he feared the Royal Society would be keen to get hold of Bartholin's Tycho papers and produce their own edition. ${ }^{14}$ The astronomical work went on into November, when the two senior scholars decided to avoid spending winter on Hven, and headed back to the relative warmth of the Copenhagen Observatory, leaving Villiard and Rømer on the island. The measurement of the seconds pendulum was carried out on Hven, and Picard records in his account of the mission that it was witnessed by both Bartholin, and Andreas Spole, professor of mathematics from the University of Lund. In a letter to Colbert, Picard reported that the agreement of both these witnesses (and the concurrence of both a Dane and a Swede to boot) made the observations all the more "authentic". He also noted, for Colbert's benefit, that the Baltic savants acknowledged that France had now become "the mother of the arts and sciences", and that this was due to Colbert (Picolet 1979). The result, Picard was happy to report, was that the seconds pendulum was found to have exactly the same length in Uraniborg as in Paris: 36 inches 8 1/2 lines (twelfths of an inch), Paris measure (Picard 1693, 12).

\section{Rømer in London, 1679}

Picard was so impressed with the work of the young Ole Rømer that he brought him back to Paris with him. Rømer spent the next 10 years based in Paris (1672-82) where he engaged in a variety of projects, building spectacular instruments for the education of the Dauphin, and working at the Observatoire on the eclipses of Jupiter's satellites (calculations which led him to argue for the finite velocity of light). At the very time of Picard's return (in 1672), another expedition of the Académie was just setting off. Giandomenico Cassini's trainee Jean Richer was leaving La Rochelle on a Senegal Company ship bound for Cayenne, where he was to conduct astronomical observations, and also to measure the seconds pendulum. From Cayenne, just under 5 degrees north of the equator, Richer was to report that the pendulum needed shortening, by a Paris line and a quarter $(2.81 \mathrm{~mm})$. This was such a small difference that most of Richer's superiors back in Paris suspected that he had made a mistake (Olmsted 1942; Dew 2008; Schaffer 2009, 261-263).

Before leaving for Denmark, Picard had asked the Royal Society to provide a pendulum measurement for London (Oldenburg 1965-1986, 7: 496-500 [Vernon to Oldenburg, 8 March 1671]). The English reported a figure of 36 inches and 4 tenths of an English foot, which-according to the conventional rates of conversionseemed to give 36 inches, 11 and 13/20 lines in Paris measures. This seemed con- 
siderably longer than the Paris length (now replicated at Uraniborg), which made Picard suspect either an error on the part of the English, or an error in the conversion from English to French units, or both. For this reason, Picard stepped up his requests for an accurate copy of the English foot standard to be made and sent to Paris. In 1679, an opportunity arose to settle the doubts over the question, by sending Ole Rømer to London. Rømer's task was to carry out the pendulum measurement-effectively to show the English how it had to be done-and to verify the exact value of the London foot. ${ }^{15}$

Rømer made the journey from Paris to London with Locke, who had met him in France and was now on his way back to England. They arrived in London in late April 1679. Rømer and Locke spent a few weeks enjoying London togetherRømer seems to have fallen for a pretty woman who ran a hardware shop ("pulchra mercatrix"), and so bought a lot of pliers and knives (Locke 1976-1989, 2: 26, 52). In late May, finally getting down to his task, Rømer went to the Greenwich observatory, where under Flamsteed's eye he began the pendulum work. Flamsteed reported that they found the length to be the same as in Paris, although he noted that Rømer had left him a pendulum ball, so that he could repeat the experiment himself later on. ${ }^{16}$ By this date, the pendulum experiment was coming under scrutiny, and the attention to both the material apparatus and to technique is reflected by the fact that Rømer left one of his pendulum bobs with Flamsteed, and by the fact that Robert Hooke and Denis Papin (Robert Boyle's assistant) visited Rømer and examined his instruments: the brass ball for the pendulum bob, his sliding steel ruler, and even the pendulum cord, made of silkgrass, an exotic hemp which the French had found to be the best material for the purpose (Hooke 1935, 412; cf. Dew 2008, 63, 70 n. 32).

By June 1679, Rømer was back in Paris, supposedly having brought the Royal Society into line with the measurements that the Académie had found in both Uraniborg and Paris. Nonetheless some doubts still remained: there were rumours that the English had changed their minds, and by September, Rømer was allowing that their might be a measurable difference between the London and Paris lengths after all (Locke 1976-1989, 2: 35 [Justel to Locke, 11 June 1679]; 91-2 [Rømer to Locke, 5 Sept. 1679]). In the following months, metal rules and pendulum balls continued to be sent between Paris and London. In the next couple of years, Picard and Philippe La Hire went on mapping missions to the SouthWest of France (to Bayonne and Sète), which appeared to provide new evidence of the non-variation of the pendulum. The only outlying figure, by this date, was Richer's from Cayenne. The next French expedition beyond Europe, to Gorée (Senegal) and the Antilles, produced a more unsettling result, since it reported an even greater shortening than that found by Richer, and at a more northerly latitude than Cayenne. However, this result failed to convince the Academicians for several years (Dew 2010).

Across the 1670s, then, Picard's project to establish the invariance of the seconds pendulum seemed to be successful. The Académie had gathered the experimental data from a range of locations which could resolve the theoretical doubt that had long existed as to the viability of the seconds pendulum as a 
universal length standard. (The theoretical doubts had more to do with the Copernican diurnal rotation of the earth rather than the shape of the earth, at this stage.) The process of replicating the pendulum measurement, and making the numbers cohere from a range of locations in Europe, was troubled—even though the actual variation in the acceleration due to gravity between Paris and London was probably too small to be measured — by the fact that this apparently simple experiment was actually difficult to do. The success of the measurement depended on knowing the correct procedure (such as making sure you set the pendulum to very small vibrations), but also on the accuracy of the timekeeping (which required a large and accurate clock as well as daily solar observations), and on material details like the proper kind of thread for the cord, the correct dimensions for the bob, or a properly-shaped metal clip from which to hang the thread. ${ }^{17}$ It was only through dogged correspondence, and the circulation of highly skilled people (Picard and Rømer), and their special apparatus, that the replications were achieved at all, and a consensus established-even while such expeditions touched upon rivalries within the supposedly cooperative Republic of Letters. A few years later, Isaac Newton's argument for the earth's having an equatorial bulge, which entailed the re-classification of Richer's figure from Cayenne as an extremely accurate measurement (Schaffer 2009), was to challenge the notion that the seconds pendulum could function as a universal measure; although the idea that it could provide a locally-specified standard was to survive throughout the eighteenth century.

\section{Conclusion}

How scientific cultures frame their most ambitious metrological projects reveals a great deal about such cultures' values. ${ }^{18}$ The dream of deriving a universal standard of measurement from a natural constant was by no means new in the seventeenth century, and it was destined to survive much later. In the seventeenth century, though, it resonated with the ideals of the scholarly community, in which appeals were made to a range of theological, humanistic, antiquarian, and "natural" forms of authority. The metrological projects of the seventeenth century can strike us as strange, as much for their references to Solomon's Temple or the Egyptian pyramids, as for their explicitly articulated connections between metrics and political sovereignty. The connection between shared standards and social order was a truism for Thévenot and his contemporaries. Thévenot's proposed honeycomb standard may or may not have been a joke - the ambiguity is itself telling — but the playful register conceals a more serious paradox. The honeycomb itself hovers on the border between art and nature, as a technical feat produced by bees. Human art must be instructed by nature's art. But by offering as a natural standard the craftwork of bees, especially with a nod to Virgil, Thévenot's fable of the bees also hints at the relationships between natural regularities and social organization, and between social orders and technical prowess. The project to make the seconds pendulum a universal unit 
was an attempt to use artificial means (clocks, pendulum apparatus, astronomical timekeeping techniques) to represent a supposed natural constant (the acceleration of falling bodies), which was assumed to be the optimal basis for a system of standards. It may at first sight appear to have had much more chance of success, and it was connected at the practical level to the newest techniques and institutions; but it was nonetheless a project that was conceived within the same scholarly culture, and endowed with some of the same values, as Thévenot's hive.

\section{Notes}

1. Dates are given in the calendar used by the source (Old Style for letters sent in England; New Style in France), except where needed for clarity. The passage continues (in de Beer's translation from Locke's Latin): “... it was rounded in shape and slightly flattened on both sides, so that it was not perfectly spherical. I hear that others were measured by various people and found to have twice as great a circumference; but the middling specimen that I handled myself sufficiently astonished me, and I should be glad to know from your philosophers up to what weight solid bodies of such bulk can be suspended in the air. I doubt whether the Cartesians can have any contrivances to help in this matter, and whether the Occult Qualities of the Peripatetics may not break down under such a load". Locke here turns from a report of a rare phenomenon to a point about natural philosophy, in a fashion typical of his letters in this period.

2. Locke explains: "When I used grys in giving the measurement of our hailstones I did so in the belief that I had once told you, when enjoying your delightful company, that this is the name I have given to $1 / 1000$ of the universal foot, so that 420 grys signifies 4 pouces 2 lines or $420 / 1000$ of that foot; but the globule that I handled myself was a very small one". For Locke's invented universal system (which incidentally happens to be decimal), see Locke to Boyle, 16 June 1679 (Locke 1976-1989, 2: 38-39 and notes), de Beer's long note on metrology at ibid., 14-16, and at $39 \mathrm{n}$. 1. See also Locke (1953), 161 (entry for 7 August 1677) and 185 (29 Jan 1678). In his travel journal, Locke frequently measured buildings and expressed the measurements in his "universal" system. For contemporary projects for decimal metric systems, see also Sarton (1935), 188-194. For background on Locke's French correspondence, see Bonno (1955).

3. Both "truquette" and "piche" remain unidentified; confusingly, an "hémine" was an ancient unit of about half a pint (Lancelot 1667) whereas an "émine" (sic) was a Montpellier unit of volume, approximating 26 litres (Zupko 1978, 62-3). The Paris pound (livre) comprised $16 \mathrm{oz}$ (onces), but various provincial pounds had fewer ounces.

4. Toinard writes: "Il est tres a souhaiter que l'on convient d'une mezure et d'un poids, mails il n'y a pas lieu d'esperer cela que dans la Caroline, ou lon taille en plein drap. Je n'oserois vous mander ce que j'ay apris depuis peu sur ce sujet a legard de ceux qui pouroient et devroient l'introduire dans un etat qui inviteroit peut-etre le reste de l'Europe a cete conformité et uniformité universele". Locke included the system in his Carolina scheme (Woolhouse 2007, 156; cf. Arneil 1996, 118-31).

5. Wilkins here gives a reasonably detailed account of how to perform the pendulum measurement, with the important exception of how to establish a reference for seconds of mean solar time.

6. Thévenot's term "diaspre du tombeau" is unclear: "diaspre" might mean a diaphanous shroud, or a kind of jasper; the stone seems more likely in this context.

7. In French, the passage reads: "Dans une entreprise que tant d'efforts inutils ont renduë comme desesperée, il m'est venu dans l'esprit que peut-estre l'on y réüssiroit mieux en se servant de quelqu'un de ces ouvrages que nous disons que les bestes font par instinct; nous pouvons ce me semble supposer avec raison que cet instinct leur venant d'une cause eternelle, il doit estre 
toûjours le mesme [et] exempt de toutes ces varietez qui distinguent tout ce qui vient des hommes. Entr'autres exemples je trouvay que les cellules des abeilles de mesme espece, mesurées dans le temps que les abeilles les bâtissent, sont égales entre elles, [et] ayant depuis mesuré celles des environs de Paris, de la Ville de Leyden, de Florence, je n'y trouvay aucune difference; [et] que si l'on suit les rangs selon lesquels les fonds ou bases de ces cellules sont disposées, l'on trouvera qu'un mesme nombre de cellules donne toûjours la mesme mesure. Ainsi rapportant toutes les mesures dont on se sert maintenant dans le monde, à celle des cellules des abeilles, la posterité pourra par ce moyen les connoistre toutes: Et cette mesure que je propose icy sera d'autant plus generale, qu'il y a des abeilles dans tous les endroits de la terre, aussibien aux lieux qui approchent des Poles, qu'en ceux qui sont plus avancez vers la ligne: Et quoy-que je l'établisse sur de la cire, rien ne m'empéche de croire qu'elle ne puisse durer autant que le monde, [et] qu'elle ne soit plus propre à ce dessein que le diaspre du tombeau sur lequel Gravius a marqué le pied Anglois, [et] plus aisée à entendre [et] à pratiquer que celle qui se peut tirer des vibrations du pendule, jointes à une observation celeste, comme on l'a voulu faire en France [et] en Pologne. Mais auparavant que de l'établir, je voudrois avoir pû comparer les ouvrages des abeilles de lieux éloignez, du Cap de Bonne Esperance [et] d'Egypte; par exemple, avec celles de la Moscovie [et] du Mexique, [etc.]. Et si elles [se] trouvent par tout égales, cette mesure se pourra rendre commune à toutes les nations, [et] par son moyen l'on pourra transmettre la connoissance des mesures de nostre siecle, à la posterité, qui est ce que l'on cherche".

8. "Ainsi l'on peut appliquer à ces ouvrieres les vers que le Poëte s'appliquoit à luy-mesme, [et] dire à leur honneur, In tenui labor, at tenuis non gloria. Ou bien souffrir qu'un Poëte Persan s'écrie avec une licence ordinaire aux Poëtes de son païs, Que si Archimede avoit examiné un ouvrage si surprenant, il se seroit mordu les doigts d'admiration avec les dents de l'envie".

9. See also the special issue of Studies in Eighteenth-Century Culture, 18 (1988), with essays by Carol Blum, Jeffrey Merrick, Ann Fairfax Withington, and Roseanne Runte.

10. Later, in the mid-eighteenth century, the geometry of the form of honeycomb cells was to be studied by Réaumur, Bazin, and Maraldi (although without the suggestion of a length standard): Fleck (1979), 32-33, and Spary (1999), 272-306.

11. As Olmsted notes $(1942,119)$, Auzout in his 1667 proposal for an expedition to Madagascar included the pendulum: Archives de l'Académie des Sciences (Paris), Registre des ProcèsVerbaux, 2: ff. 43-50, at f. 49.

12. Picard to Cassini, 11/21 August 1671, Bibliothèque de l'Observatoire, ms B.4.11bis, bundle "Picard", letter 1 (sent from Hamburg).

13. Picard found the ratio of the Rhenish foot to the Paris foot to be 696:720, rather than 695:720, as had previously been thought, which implies that his measuring instruments were capable of distinguishing between sixtieths of an inch (Picard 1693, 2-3; reprint MARS, 7 (1), 194-5).

14. Bibliothèque de l'Observatoire (Paris), ms B.4.11bis, bundle "Picard", letter 7 (Picard to Cassini, 13 Feb. 1672): "les Anglois ont fait leur possible pour auoir les originaux, mais enfin nous sommes maitres".

15. These twin aims are made clear in Archives de l'Académie des Sciences (Paris), Registre des Procès-Verbaux, 7: f. 240v (8 April 1679): "Mr Roemer a fait voir les instruments qu'il porte en Angleterre pour obseruer la longueur de la pendule, et verifier la longueur du pied de Londres."

16. Flamsteed (1995-2002), 1: 690-92, Flamsteed to Towneley, 3 and 22 May 1679. Flamsteed reports (692, 22 May): "wee tried here the length of a pendulum that vibrates seconds and found it 39 1/8 inches English Measure, or of the Paris $3671 / 100$ hee has left a ball of the same weight with mee wherewith I intend to repeate the Experiment at my first leasure"; 36.71 inches is an approximation of the value that the Académie des Sciences was now using as its usual value for Paris (usually expressed as 36 inches, 8 1/2 lines).

17. For remarks on replication and craft skill in a contemporary context, see (among others) Collins (1992), and Collins (2001).

18. For metrology in the sociology of science, more generally, see Latour 1987, 247-57; O'Connell 1993; Mallard 1998; Schaffer 2000. 
Acknowledgement I would like to thank all the participants at the Baroque Science workshop at the University of Sydney for their help with this essay, and especially Ofer Gal and Raz Chen-Morris.

\section{References}

Alder, Ken. 1995. A revolution to measure: The political economy of the metric system in France. In The values of precision, ed. M. Norton Wise, 39-71. Princeton: Princeton University Press.

Allen, Danielle. 2004. Burning the fable of the bees: The incendiary authority of nature. In The moral authority of nature, ed. Lorraine Daston and Fernando Vidal, 74-99. Chicago: University of Chicago Press.

Armogathe, Jean-Robert. 2001. Un seul poids, une seule mesure: le concept de mesure universelle. XVIIe siècle 213: 631-640.

Arneil, Barbara. 1996. John Locke and America: The defence of English colonialism. Oxford: Clarendon Press.

Bacon, Francis. 2000. The new organon, ed. Lisa Jardine (trans: Silverthorne, Michael). Cambridge: Cambridge University Press.

Baker, Keith M. 1990. Inventing the French revolution: Essays on French political culture in the eighteenth century. Cambridge: Cambridge University Press.

Bennett, Jim, and Scott Mandelbrote. 1998. The garden, the ark, the tower, the temple: Biblical metaphors of knowledge in early modern Europe. Oxford: Museum of the History of Science/ Bodleian Library.

Bernier, François. 1992 [1671]. Requeste des Maistres ès Arts, Professeurs et Regens de l'Université de Paris, présentée à la cour souveraine de Parnasse. In Corpus: revue de philosophie, ed. Sylvia Murr, 20-21: 231-239.

Blamont, Jacques. 2001. La mesure du temps et de l'espace au XVIIe siècle. XVIIe siècle 213: 579-611.

Bodin, Jean. 1583 [1576]. Six Livres de la République. Paris: Jacques Dupuis.

Bodin, Jean. 1992. In On sovereignty, ed. Julian H. Franklin. Cambridge: Cambridge University Press.

Bonno, Gabriel D. 1955. Les Relations intellectuelles de Locke avec la France, d'après des documents inédits. Berkeley/Los Angeles: University of California Press.

Burke, Peter. 1997. Fables of the bees: A case-study in views of nature and society. In Nature and society in historical context, ed. Mikuláš Teich, Roy Porter, and Bo Gustafsson, 112-123. Cambridge: Cambridge University Press.

Cassini, Giandomenico. 1693. De l'origine et du progrès de l'Astronomie, et de son usage dans la Geographie et dans la Navigation. In [Académie des Sciences], Recueil d'Observations faites en plusieurs voyages par ordre de Sa Majesté, pour perfectionner l'astronomie et la géographie. Separately paginated, 43 pages. Paris: Imprimerie royale. Reprinted in Memoires de l'Académie Royale des Sciences, 1666-99, 8: 1-52.

Collins, Harry. 1992. Changing order: Replication and induction in scientific practice. 2 nd ed. Chicago: University of Chicago Press. (Orig. ed. 1985.)

Collins, Harry. 2001. Tacit knowledge, trust and the Q of sapphire. Social Studies of Science 31(1): $71-85$.

Costabel, Pierre. 1987. Picard et l'étalon universel de longueur fondé sur le pendule. In Jean Picard et les débuts de l'astronomie de précision au XVIIe siècle, ed. Guy Picolet, 315-328. Paris: CNRS.

Cumberland, Richard. 1686. An essay towards the recovery of the Jewish measures and weights, comprehending their monies, by help of ancient standards, compared with ours of England. London: Richard Chiswell, printer to the Royal Society.

Defossez, Léopold. 1946. Les Savants du XVIIe siècle et la mesure du temps. Lausanne: Edition [sic] du Journal Suisse d'Horlogerie et de Bijouterie. 
Dew, Nicholas. 2006. Reading travels in the culture of curiosity: Thévenot's collection of voyages. Journal of Early Modern History 10(1-2): 39-59.

Dew, Nicholas. 2008. Vers la ligne: circulating measurements around the French Atlantic. In Science and empire in the Atlantic world, ed. James Delbourgo and Nicholas Dew, 53-72. New York: Routledge.

Dew, Nicholas. 2009. Orientalism in Louis XIV's France. Oxford: Oxford University Press.

Dew, Nicholas. 2010. Scientific travel in the Atlantic world: The French expedition to Gorée and the Antilles, 1681-1683. British Journal for the History of Science 43: 1-17.

Findlen, Paula. 1990. Jokes of nature and jokes of knowledge: The playfulness of scientific discourse in early modern Europe. Renaissance Quarterly 43: 292-331.

Findlen, Paula. 1994. Possessing nature: Museums, collecting and scientific culture in early modern Italy. Berkeley/Los Angeles: University of California Press.

Findlen, Paula. 1998. Between carnival and lent: The scientific revolution at the margins of culture. Configurations 6(2): 243-267.

Flamsteed, John. 1995-2002. The correspondence of John Flamsteed, the first astronomer royal, ed. E.G. Forbes, L. Murdin, and F. H. Willmoth, 3 vols. Bristol: Institute of Physics.

Fleck, Ludwik. 1979. Genesis and development of a scientific fact (trans: Bradley, Fred and Thaddeus J. Trenn). Chicago: University of Chicago Press.

Freedberg, David. 2002. The Eye of the Lynx: Galileo, his friends, and the beginnings of modern natural history. Chicago: University of Chicago Press.

Giustini, Pietro Alessandro. 1992. Tito Livio Burattini e la nascita della metrologia scientifica. In La matematizzazione dell'universo: momenti della cultura matematica tra '500 e '600, ed. Lino Conti, 360-362. Assisi: Porziuncola.

Greaves, John. 1647. A discourse of the Romane foot, and denarius: from whence, as from two principles, the measures and weights, used by the ancients, may be deduced. London: Printed by M. F. for William Lee.

Hartlib, Samuel. 1655. The reformed common-wealth of bees: Presented in severall letters and observations to Samuel Hartlib, Esq. London: Printed for Giles Calvert.

Haustein, Heinz-Dieter. 2001. Weltchronik des Messens: Universalgeschichte von Mass und Zahl, Geld und Gewicht. Berlin: De Gruyter.

Heilbron, John L. 1993. Weighing imponderables and other quantitative science around 1800. Historical studies in the physical and biological sciences: Supplement to vol. 24, part 1. Berkeley: University of California Press.

Hooke, Robert. 1935. In The diary of Robert Hooke, M.A., M.D., F.R.S., 1672-1680, ed. H.W. Robinson and W. Adams. London: Taylor \& Francis.

Huygens, Christiaan. 1986 [1673]. The pendulum clock, or geometrical demonstrations concerning the motion of pendula as applied to clocks (trans: Blackwell, Richard J., with an introd. by H. J. M. Bos). Ames: Iowa State University Press, 1986.

Johns, Adrian. 1998. The nature of the book: Print and knowledge in the making. Chicago: University of Chicago Press.

Koyré, Alexandre. 1953. An experiment in measurement. Proceedings of the American Philosophical Society 97(2): 222-237.

Kula, Witold. 1985 [1970]. Measures and men (trans: Szreter, R.). Princeton: Princeton University Press.

Lancelot, Claude. 1667. Dissertation sur l'Hemine de Vin, et sur la Livre de Pain de S. Benoist, et des autres anciens Religieux. Paris: Charles Savreux.

Latour, Bruno. 1987. Science in action: How to follow scientists and engineers through society. Cambridge: Harvard University Press.

Lewis, Rhodri. 2007. Language, mind, and nature: Artificial languages in England from Bacon to Locke. Cambridge: Cambridge University Press.

Locke, John. 1953. In Locke's travels in France, 1675-1679: As related in his journals, correspondence and other papers, ed. John Lough. Cambridge: Cambridge University Press.

Locke, John. 1975. In An essay concerning human understanding, ed. P.H. Nidditch. Oxford: Clarendon. 
Locke, John. 1976-1989. The correspondence of John Locke, ed. E.S. de Beer, 8 vols. Oxford: Clarendon Press. Also available from Intelex Past Masters, at: http://library.nlx.com/

Mallard, Alexandre. 1998. Compare, standardize and settle agreement: On some usual metrological problems. Social Studies of Science 28(4): 571-601.

Matthews, Michael R. 2000. Time for science education: How teaching the history and philosophy of pendulum motion can contribute to science literacy. New York/Boston/Dordrecht: Kluwer Academic/Plenum Publishers.

McKeon, Robert M. 1965. Etablissement de l'astronomie de précision et œuvre d'Adrien Auzout. Doctoral thesis, University of Paris.

Mouton, Gabriel. 1670. Nova mensurarum geometricarum Idea: Et nova methodus eas, et quascumque alias mensuras communicandi, et conservandi in posterùm absque alteratione. In Mouton, Observationes diametrorum solis et lunce apparentium, meridianarúmque aliquot altitudinum Solis et paucarum fixarum, 427-48. Lyon: Matthæi Liberal.

O'Connell, Joseph. 1993. Metrology: The creation of universality by the circulation of particulars. Social Studies of Science 23(1): 129-173.

Oldenburg, Henry. 1965-1986. The correspondence of Henry Oldenburg, ed. A.R. Hall and M.B. Hall, 13 vols. Madison, Milwaukee, and London: University of Wisconsin Press.

Olmsted, John W. 1942. The scientific expedition of Jean Richer to Cayenne (1672-1673). Isis 34: $117-128$.

Olmsted, John W. 1960. The voyage of Jean Richer to Acadia in 1670: A study in the relations of science and navigation under Colbert. Proceedings of the American Philosophical Society 104(6): 612-634.

Pedersen, Kurt Møller. 1987. Une mission astronomique de Jean Picard: le voyage d'Uraniborg. In Jean Picard et les débuts de l'astronomie de précision au XVIIe siècle, ed. Guy Picolet, 175-203. Paris: CNRS.

Picard, Jean. 1671. Mesure de la Terre. Paris: Imprimerie royale. Reprinted in Memoires de l'Académie Royale des Sciences, 1666-99, 7 (1): 133-192.

Picard, Jean. 1693 [1680]. Voyage d'Uranibourg, ou Observations astronomiques faites en Dannemarck par Monsieur Picard de l'Académie Royale des Sciences. In [Académie des Sciences], Recueil d'Observations faites en plusieurs voyages par ordre de Sa Majesté, pour perfectionner l'astronomie et la géographie. Separately paginated fascicule (29 pp). Paris: Imprimerie royale. Reprinted in Memoires de l'Académie Royale des Sciences, 1666-99, 7(1): 193-232.

Picolet, Guy. 1979. Une lettre inédite de l'abbé Picard à Colbert (13 octobre 1671). XVIIe siècle 125: 389-395.

Pliny, the elder. 1991. Natural history: A selection (trans: Healy, John F.). Harmondsworth: Penguin

Raylor, Timothy J. 1992. Samuel Hartlib and the commonwealth of bees. In Culture and cultivation in early modern England: Writing and the land, ed. Michael Leslie and Timothy J. Raylor, 91-129. Leicester: Leicester University Press.

Sarton, George. 1935. The first explanation of decimal fractions and measures (1585). Together with a history of the decimal idea and a facsimile (no. XVII) of Stevin's Disme. Isis 23(1): 153-244.

Schaffer, Simon. 2000. Modernity and metrology. In Science and power: The historical foundations of research policies in Europe, ed. L. Guzzetti, 71-91. Luxembourg: European Communities.

Schaffer, Simon. 2009. Newton on the beach: The information order of Principia mathematica. History of Science 47: 243-276.

Shalev, Zur. 2002. Measurer of all things: John Greaves (1602-1652), the great pyramid, and early modern metrology. Journal of the History of Ideas 63(4): 555-575.

Spary, Emma. 1999. The nature of enlightenment. In The sciences in enlightened Europe, ed. William Clark, Jan Golinski, and Simon Schaffer, 272-306. Chicago: University of Chicago Press.

Thévenot, Melchisédech. 1681. Discours sur l'art de la navigation. In Thévenot, Recueil de voyages. Paris: Estienne Michallet. Separately paginated. 
Virgil. 1982. The Georgics (trans: Wilkinson, L.P., Penguin Classics). Harmondsworth: Penguin Wilkins, John. 1668. An essay towards a real character, and philosophical language. London: S. Gellibrand, and John Martyn, printer to the Royal Society.

Woolfson, Jonathan. 2010. The renaissance of bees. Renaissance Studies 24(2): 281-300.

Woolhouse, Roger. 2007. Locke: A biography. Cambridge: Cambridge University Press.

Zupko, Ronald Edward. 1978. French weights and measures before the revolution. Bloomington: Indiana University Press. 